\title{
Must Abolish Racial Hate to INSURE LASTING PEACE
}

\author{
Hon Sir John Salmond
}

\section{THIS ALONE CAN SECURE RESULTS OF DISARMAMENT CONFERENCE FOR NATIONS, SAYS SIR JOHN SALMOND, NEW ZEALAND REPRESENTATIVE}

This is the eighteenth of a series of articles which the Crimson is running on the Washington Conference and is substantially the same as an address which the Honourable Sir John Salmond delivered to the students of the Harvard Law School recently.

Although the international conference for the limitation of armaments has not fully completed its great task, it has already progressed so far that there is little doubt as to the nature of the results which will be attained. It was called together with high hopes and farseeing statesmanship by the Government of the United States. I believe that these hopes will not be disappointed and that that statesmanship will be fully justified. The cynics may have scoffed and the pessimists doubted, but they will be confounded. The agreement which has been, in effect, arrived at and which is to be signed for the reduction and limitation of naval armaments is one which will be a landmark in the history of international relations. ${ }^{1}$ It is impossible, however, to watch that Conference at work without mixed feelings of fear as well as hope of dejection as well as exultation. Who are these men gathered round the Council table? They are the representatives of the five nations, which after the very ordeal of the great war, alone survive as the great powers of the world, namely the British Empire,

* Judge of the Supreme Court of New Zealand and representative of New Zealand at the Conference for the Limitation of Armaments. This is a report originally appearing in the Harvard Crimson, Cambridge (Mass), 26 January 1922.

1 Salmond was referring to the Treaty for the Limitation of Naval Armament 1922. Ministry of Foreign Affairs and Trade, New Zealand Consolidated Treaty List: Part 1 Multilateral Treaties (1997) 84. Salmond's optimism concerning the Treaty can be contrasted with the more recent observation of one commentator: "That it handed over strategic command of the Western Pacific to the Japanese, although recognised by both British and American naval men of the time, did not become fully apparent until 1941...". Roskill, Hankey: Man of Secrets, Vol II (1919-1931) (Collins, London, 1972), quoted in Alex Frame, Salmond: Southern Jurist (Victoria University Press, Wellington, 1995) 215. 
France, Italy, Japan and the United States of America. Three years ago these five powers stood side by side as friends and allies in the greatest armed contest of all history. Together they triumphed in the cause of liberty, after facing together the deadliest peril to which that cause had ever been exposed. Surely after such dangers, labours, sacrifices and achievements in a common cause, it might have been anticipated that these five riations would be bound together for all time in such enduring bonds of friendship that war between them would have become incredible and schemes for mutual disarmament superfluous. But human nature has not yet risen to those heights. Underneath all the genuine hope, aspiration and goodwill, which undoubtedly animates the Washington Conference there lies a grim and disquieting significance - the recognised possibility even at this day, of armed and tragic conflict between powers which yesterday were banded together in a comradeship of arms. ${ }^{2}$ Ten years ago, notwithstanding all the talk of war and all the preparations for war that resounded through the world, a philosophic spirit might reasonably have concluded that war between civilised nations was a thing no longer possible - was a mere tradition of the evil past, and not a living possibility of the present and the future. The great was has put an end to all such optimistic illusions. And so we have seen at Washington the great powers who were friends and allies in that war looking at each other with sombre and doubting eyes as potential enemies, measuring their forces, and recognising the urgent need of mutual agreement for the limitation of their warlike preparations against each other.

If, however, the need of such a conference is a disquieting feature of our international life, its success is a matter of gratification to all the friends of justice and of peace, inspired by the sincerity, courage and statesmanship of the Government of the United States and animated by goodwill and good faith on the part of all of them, the great powers are on the eve of coming to an agreement, the like of which has never before been heard of. They purpose not only to limit for the future their preparations for naval warfare but also forthwith to destroy a great part of their existing fleets. They purpose to offer up those fighting ships as a public sacrifice on the altar of peace.

\section{WARSHIP IMPRESSIVE WORK}

A great modern ship of war is, I suppose, the most impressive of all the works of men's hands. It is the last word in that age-long process by which man has called to his aid all the forces of nature and made them do his bidding. It is the emblem of all the skill, the cunning, the courage and the indomitable will which has enabled mankind to dominate the world. It is the most terrible of all the instruments which the fierce spirit of man has forged for the fulfilment of his purposes. The day on which so many of these great engines of destruction are formally and publicly themselves destroyed as a pledge of goodwill and peace, will

2 The Naval Limitation Treaty expired, in accordance with its terms, on 31 December 1936 after Japan gave notice on 29 December 1934 of its intention to terminate the Treaty. 
surely be a memorable one in the annals of mankind. It will be an act well worthy of that great age in which we live.

We are probably too close to them as yet to realise fully the true quality of the present times. The years since the outbreak of the war will be recognised for centuries to come as the heroic age of human history. Never before in recorded times has mankind risen to such heights of achievement. Never before has this world been so lit up by the tragic splendours of human destiny or have men answered to the call of fate with so great a response of courage, serenity, resolution and self sacrifice. The eyes of this generation have looked on things which in past times it did not enter into the heart of man to conceive, and things which we trust the world will never look upon again. That the human race is steadily climbing upwards along the steep and difficult road of progress and enlightenment it is not presumptuous to hope or even to believe. That the world is destined to become greater, nobler, and happier, in the future than it has ever been in the past, I do not choose to doubt. But this very progress will serve to make more visible and more startling the heroic quality of this age in which we live. Our descendants for centuries will look back with wonder and admiration on that breed of men whose titanic virtues and vices, achievements and failures rendered so resplendent and so tragic the history of these years.

\section{NAVAL REDUCTION LONG STEP}

The limitation of the battle fleets of the five great powers is a long step forward in the way of permanent peace. It puts an end once for all to insensate competition in naval armament - a competition which has no limit except the financial resources of the states and no end except their financial exhaustion. A modern capital ship of war costs something like seven million pounds sterling and the cost is steadily increasing as these monstrous engines grow in size and complexity. If we consider the other uses to which so vast a sum of money could be put - what such a sum alone means in respect of the arts of peace - what institutions of science, art, learning, or philanthropy could therewith be established or endowed - we shall realise that an international treaty which puts an end, even for a period of years if not in perpetuity, to the building of such ships, is in its economic aspect alone a success by which this conference will be fully justified. The proposed treaty has, however, other and more important aspects than the economic. It serves also to allay the mutual fear, suspicion and antagonism which the competitive building and maintenance of great rival fleets infuses into the minds of rival states. It provides a breathing space in which mutual confidence may grow up in place of mutual distrust, in which international cooperation may be substituted for competition. It takes away also that potent temptation to actual war which is afforded by the building of great fleets, the temptation to destroy a dangerous enemy while yet there is time. It is also worthy of remark that the mere making and existence of an agreement for the limitation of armament has, apart from the actual terms of the agreement, an important moral effect on the consciences of the nations concerned. It is not possible for civilised 
representatives of civilised states to discuss together in personal intercourse the regulation of instruments of mutual destruction without the growth of that spirit of mutual understanding, which is in itself a powerful guarantee that those instruments will never be called into actual use.

\section{HOPED TO GO FURTHER}

We had thought to go further along the road of disarmament than the mere limitation of the number of capital ships. The British Empire had in particular sought the total abolition of an instrument of naval warfare, which during the late war was found by terrible experience to be inconsistent with the dictates of humanity. In this aim we did not fully succeed. It is certain, however, that in the public opinion of this country and I believe in the public opinion of other countries the views expressed by Great Britain meet with a very considerable volume of sympathy and support. It is not an unreasonable hope that at some not distant date, before the memory of the Lusitania and the Britannic has faded from the public mind, the building and maintenance in times of peace of these instruments of inhumanity in time of war will be prohibited. It is true that the powers assembled at this conference although refusing to prohibit the submarine, have agreed on rules intended to restrict its use within the limits imposed by humanity. ${ }^{3}$ We cannot fail to realise the importance of this attempt to reform the laws of war. We must all recognise the admirable motives by which that attempt has been inspired. We must all desire most earnestly that it should succeed. But I confess with regret that I doubt the permanent efficacy of any rules which purport to tie the hands of belligerent nations when war has actually broken out, and they are fighting for their existence. In such an extremity we may fear without cynicism that nations will act on the maxim that necessity knows no law, that in war the laws are silent and that every road to selfpreservation and victory is justified. Notwithstanding all the endeavours of international law to render war more humane the tendency of the growth of scientific knowledge is to make war more terrible and more relentless than it has ever been in the past. The best way of reform lies not in any such endeavour to restrict the rights and activities of states when actually at war, but in an endeavour so to limit and regulate the permissible preparation for war in time of peace that war when it comes will be deprived of ready-made instruments of inhumanity and so freed from the temptation to use them. Such laws will be readily obeyed in times of peace and their effects will be operative for good in time of war. But laws made for war itself will for the most part prove too fragile

3 The relevant Treaty relating to the use of submarines and noxious gases in warfare did not enter into force. Frame discusses it in Salmond: Southern Jurist above n 1, 211-213. 
to stand the strain that will be put upon them by the grim necessities of self defence and self preservation. 4

\section{IS EVENT OF DEEP IMPORTANCE}

Although, therefore, the agreement contemplated by the five great powers falls short of the scope which was hoped for, it will nevertheless be an event of deep importance in the history of the relations of those states. The step so taken is one for which the world owes a debt of gratitude to the United States. Of all countries, this is the richest and therefore potentially the most powerful. It had the opportunity, therefore, if it had thought fit, to lead the rest of the world along the ruinous and lamentable road of naval and military competition. Great as were the efforts, the sacrifices and the services of the United States in the recent war - efforts, sacrifices, and services which the British Empire more especially will never forget, and for which she will never fail in gratitude - your country has not, like the others, been exhausted financially and all but broken in spirit by the burdens, anxieties and sorrows, which they have borne and which they still bear. You are not, like Europe, war-weary and sick at heart. All the more credit, therefore, is due to the Government of this great nation and to the public conscience on which that Government is based, that the temptation of this opportunity has been put behind you, and that you have shown yourselves ready and willing to walk in the way of peace rather than in that of war and warlike preparation.

Great as are the benefits that are to be had from such an international agreement it is necessary to avoid distorted views of its significance and purpose. The conference at Washington has been commonly referred to as a disarmament conference. Its true purpose, however, is not disarmament, but the limitation of armament - not the abolition of all instruments and preparations for national defence and the use of international force but the restriction within reasonable limits of such instruments and preparations in time of peace. As human nature is at present constituted there can be no talk, to any useful purpose, of disarmament. We cannot find peace by any such simple process as that of beating all our swords into ploughshares. Military and naval power is an essential and permanent element

4 Salmond saw state power in situations of civil emergency or state peril as unconstrained by the law. This is consistent with Salmond's view of the state "as the source, not merely the instrument, of law... ". Salmond: Southern Jurist above n 1, 162. Salmond gave expression to his strong view of state power in his opinion to the government in the 1913 waterfront crisis, where he stated: "By the common law it is not only the right but the duty of the Police and of all Magistrates and Officers to use their best endeavours to maintain the King's peace, and for this purpose to use such force and to take all such other measures as are reasonably deemed necessary... All such acts, although otherwise illegal, are justified in law by the necessity of the case...". Salmond: Southern Jurist above n 1, 162. As Solicitor-General during World War One, Salmond ordered censorship of mail, despite being aware that there was no legislative basis for his actions Salmond: Southern Jurist above n 1, 176-7. 
of organised human society. A world without war is a noble and reasonable aspiration, which has in all ages appealed to the hearts and consciences of men. But a world without reasonable provision for the grim possibility of war - a world in which armed force had ceased to be recognised as a necessary instrumentality of peace itself - would have no true relation to the facts of human nature and would be merely an opportunity for anarchy and crime. Self-defence against lawless violence, whether it is the violence of individuals or that of other communities, is a permanent and essential function of the state. To abolish armies and navies because we object to war, would be as unreasonable as to abolish the police force because we object to crime.

\section{MUST ABOLISH CAUSES}

The true and only method of securing permanent peace is to abolish the causes that lead to war. One of those causes is to be found in the conflict of material interests. Rivalries of territorial and economic expansion have constantly sought satisfaction to the use of force. This cause, however, is steadily disappearing. The process of dividing up this world and its opportunities between the rival states is already all but completed. There is no longer much scope for genuine disputes as to mine and thine or of honest quarrels as to the rights of nations. Such material interests as continue to be possible subjects of international dispute are so small in importance compared with the cost of maintaining them by war, that if this was the sole consideration, they would create no danger of any disturbance of the public peace. Unfortunately, however, for the welfare of mankind this is not the sole consideration. There is a deeper and more dangerous influence at work, an influence that is essentially irrational, and is therefore beyond the control of mere reasoned considerations of the public interest. Nations are not solely moved by reasons of self-interest. They are moved by the emotions of racial pride and racial antagonism, and it is from the dangerous and deadly influence of these feelings that the chief and abiding peril of the world proceeds. It is one of the lamentable features of human nature that every separate community tends to develop a conscience and spirit of its own which is distinct from, and antagonistic to those of other communities, and which excludes that common conscience and common spirit which ought to bind the whole human race together as one society. The result is the growth of national animosities, misunderstandings, suspicions, fears - feelings which however long they may slumber or lay latent are capable at any time of flaming out into the tragedy of international conflict. This racial feeling which divides mankind into separate subspecies emotionally antagonistic to each other is essentially evil. The future of civilisation demands that so far as may be, it should be eliminated from the world. Men must learn that from north to south, from east to west, they are all of one blood and of one family and until they learn that hard lesson there will be no security for the cause of peace and righteousness. No agreement for the limitation of fleets or armies can in itself be an adequate substitute for this necessary change of heart. It is easy for this deadly and dangerous vice of racial antagonism to masquerade under the guise of patriotism. But they are very different things. The virtue 
of patriotism consists in the love of one's own country and the will to serve it to the utmost. The vice of racial antagonism consists in dislike, suspicion, fear, contempt and arrogance in respect of other countries and of our fellow beings who belong to them. If there is to be any sure and certain hope of peace on earth this evil spirit must be exorcised, and goodwill towards men of every race must take its place. That this will come about in time I do not doubt. There is, however, but little encouragement to be derived from a study of the tendency of recent years and of the present day. Much is being said and done to promote this evil spirit rather than to eliminate it. Much is being said and done to encourage the growth of the disruptive instincts of racial pride and ill-will rather than to promote unity and harmony of the human race. Many men sometimes with good intentions have been and are busy in this way in doing the devil's work. I trust indeed that this is merely a temporary aberration of the human spirit. But however this may be as to the world at large, there are two great nations between which all national antagonism is here and now intolerable. If the British Empire and the United States of America cannot live together in indissoluble bonds of friendship and goodwill what hope is there for the rest of mankind? I know ell that there are evil influences and evil men in your country and in mine who are engaged in sowing the seed of discord. But I trust and believe that these seeds will fall on barren ground. I know well that in the past we have had our quarrels and our causes of enmity and distrust. But I believe that we are wise enough to let the dead past bury its dead. What in God's name have the crimes and follies of our ancestors to do with us? If the shadow of an evil past lies over the pathway towards a glorious future let us consign the past to a deserved oblivion. It is certain that these two great countries are already so bound together by the ties of kinship, friendship and common interests that actual war between them has become a thing which is inconceivable - a crime at which the angels in heaven would hide their faces - a folly at which civilisation would abandon hope. But we may well look forward to something better than the merely negative achievement of an armed peace. What the cause of righteousness demands from us is active, whole-hearted goodwill and loyalty unpolluted by any elements of bitterness, suspicions, jealousy or pride, so that these two greatest nations of the earth may go side by side in the path of civilisation, speaking in all things with one mind and one voice. We may reasonably hope that the not distant future will see the fulfilment of this aspiration. It is certain that in such fulfilment lies the hope of the human race. 
